\title{
Impacts of Public Support and Voices Pluralism in Macao
}

\section{Newspapers}

\author{
José Manuel Simões \\ Saint Joseph University, Macao, China \\ Paulo Faustino \\ Porto University, Porto, Portugal
}

\begin{abstract}
The economic and financial sustainability of regional press companies is extremely relevant for the dynamism of this important sector in promoting pluralism of ideas and decentralization of information. In this context, the work presented here intends, on one hand, to analyze the importance of the press support system in Macao for its economic and financial sustainability and, on the other hand, to try to understand how they contribute to promoting information pluralism with Portuguese speaking community in a Chinese territory-with special regime. With this purpose, three methodologies were implemented, namely: (1) review of literature and documentary research — reports, articles in the press, scientific articles and academic books related to the topic; (2) analysis of contents of interviews of privileged informants-directors and editors of newspapers addressed to the Portuguese community in the Macao region; and (3) analysis of the impact of support from the Macao Regional Government based on the principles of the Office of Fair Trading (OFT) model.
\end{abstract}

Keywords: pluralism, voices, sustainability, subsidies, market and newspapers

\section{Context, Methodology and Objectives of the Research}

\section{Theme Context}

In Macao, as it happens in Portugal, the regional press market segment is mainly made up of micro, small and medium-sized enterprises. Its target market is mainly limited to the geographic area (locality, parish, county) of each company - which ends up conditioning its expansion vectors. The regional press sector is particularly vulnerable to the typical blockages created by the shortage of demand in the two main markets of media companies: circulation market and advertising market.

Although the Special Autonomous Region of Macao has a special regime and operates as an autonomous territory, with its territorial dimension, the number of potential readers and the characteristics of the newspapers addressed to the Portuguese community that lives there, it is possible to classify and to bring together the journalistic model of the Macao's newspapers with the local and regional newspapers published in Portugal. However simple this comparison may be, it is clear that the information market is really small compared to the multiplicity of newspapers (5) - the daily newspapers Jornal Tribuna de Macau, Ponto Final and Hoje Macau

José Manuel Simões, Assistant Professor and Director of the Department of Communication and Media, Saint Joseph University.

Paulo Faustino, Assistant Professor, Department of Communication and Information Sciences, Porto University. 
and the weekly newspapers Clarim, trilingual, and Platforma (2014), bilingual, that are published in the territory in Portuguese.

For the existence of these newspapers - and their economic and financial viability-it will not be irrelevant to analyze the role and impact that result from the subsidies granted by the SARM Government. Table 1 shows an X-ray of the ownership of media companies in Macao, namely at the newspaper level.

Table 1

Radiography of the Ownership of the MSAR Media Companies

\begin{tabular}{|c|c|c|c|c|c|c|}
\hline Name of Media & Radio & Television & Newspaper & Magazine & Online & Owner \\
\hline DAILYPONTO FINAL & & & $\mathrm{X}$ & & & Ricardo Pinto \\
\hline $\begin{array}{l}\text { DAILYJORNAL } \\
\text { TRIBUNA DE MACAU }\end{array}$ & & & $\mathrm{X}$ & & & $\begin{array}{l}\text { Tribuna de Macau - Empresa } \\
\text { Jornalística e Editorial, SARL", a } \\
\text { joint-stock company managed by } \\
\text { José de Rocha Dinis }\end{array}$ \\
\hline DAILYHOJE MACAU & & & $\mathrm{X}$ & & & $\begin{array}{l}\text { Fábrica de Notícias, administrated } \\
\text { by Carlos Morais José }\end{array}$ \\
\hline WEEKLYO CLARIM & & & $\mathrm{X}$ & & & Diocese de Macau \\
\hline WEEKLYPLATAFORMA & & & $\mathrm{X}$ & & & $\begin{array}{l}\text { Plataform Multimedia Projects, } \\
\text { administrated by Paulo Rego }\end{array}$ \\
\hline $\begin{array}{l}\text { TDM - TELEVISÃ O DE } \\
\text { MACAU }\end{array}$ & & $\mathrm{X}$ & & & & Public-Private Enterprise \\
\hline $\begin{array}{l}\text { RÁDIO MACAU } \\
\text { REVISTA MACAU }\end{array}$ & $\mathrm{X}$ & & & $\mathrm{X}$ & & $\begin{array}{l}\text { Public-Private Enterprise } \\
\text { Macao Government Information } \\
\text { Bureau }\end{array}$ \\
\hline
\end{tabular}

Note. Source: Own elaboration based on dispersed information.

It may be said that the regional press plays a pivotal role in what concerns the promotion of the pluralism and diversity of information, ideas and values - meaning: if, on one hand, the regional press is essential in the territorial context, on the other hand, its contribute won't be less important to the maintenance and narrowing of ties between the local population and the migrant communities, forming a true vehicle of dissemination of information to which, many times, the national or international press is sensible.

Therefore, the regional press may fulfill a cultural function that should not be unrelated to any media. In this sense, the work presented here aims at analyzing the importance of the press support system in Macao for its economic and financial sustainability as well as trying to understand the extent to which they contribute to promoting information pluralism with the Portuguese-speaking community living in Chinese territory.

\section{Methodology and Objectives of the Work}

This work is based on three main methodologies, notably (1) review of literature and documentary research—reports, articles in the press, scientific articles and academic books related to the topic; (2) analysis of interviews' contents of privileged informants-directors and editors of newspapers addressed to the Portuguese community in the Macao region; and (3) analysis of the impact of the supports from the Macao Regional Government based on the principles of the "Office of Fair Trading (OFT)" model, explained with further detail in the next section of the literature review.

It is important to understand, as the OFT (2007, p. 5) suggests, that, only by itself, a subsidy does not determine the mechanisms that assure the effectiveness and the proper working of the market, seeing that: (1) the competitors are forced to leave the market, to reduce their long-term investments or, for instance, to reduce 
employment, in order to assure their survival in short term; (2) the subsidy's beneficiary is under small financial pressure to be competitive; (3) an inefficient beneficiary may stay in the market or close activity, since the subsidy wasn't enough to reverse the situation; and (4) for market participants, it's worth spending large sums of money searching subsidies. The OFT assumptions, outlined in Figure 1, stem from the interaction of six variables that influence each other mutually.

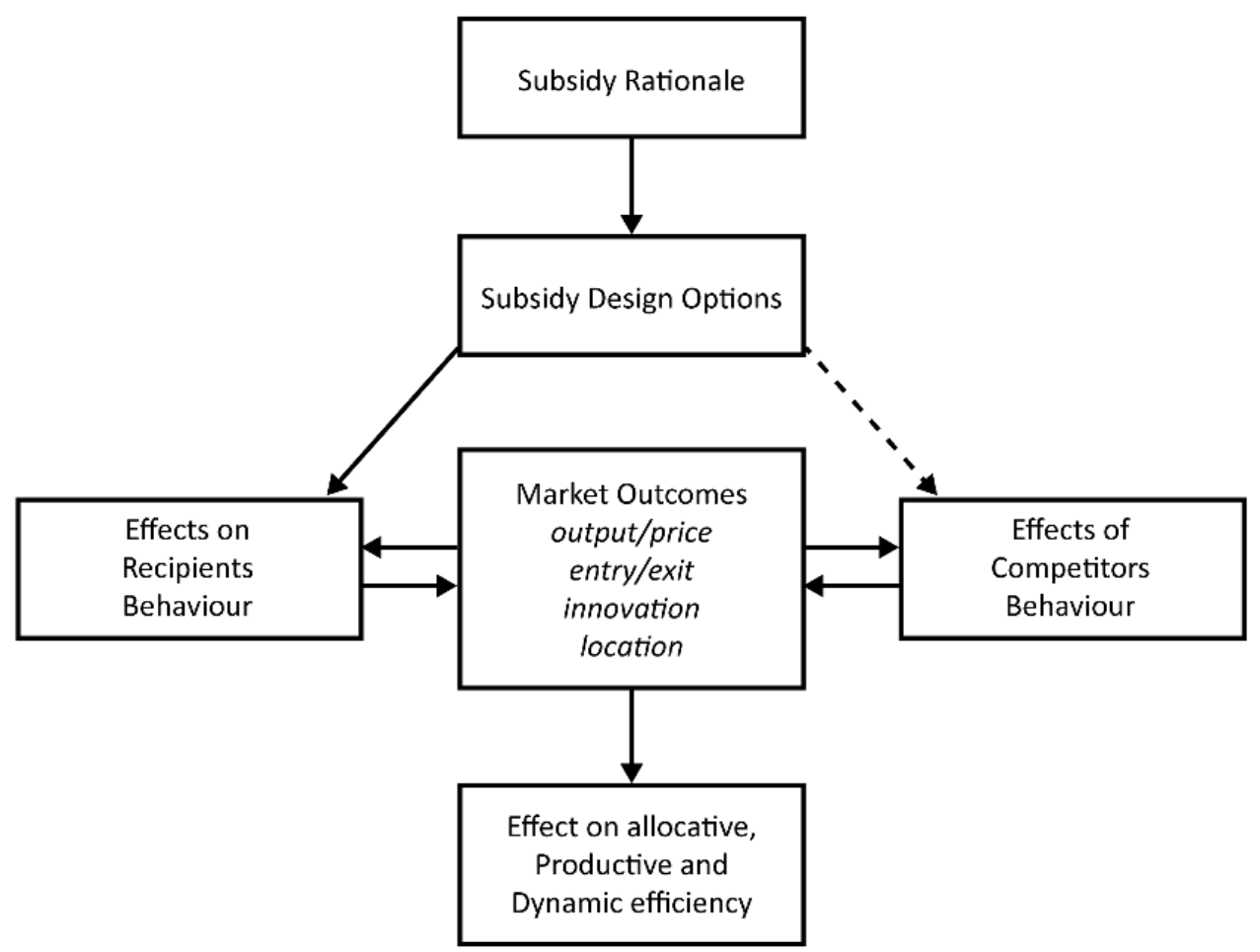

Figure 1. The OFT model and impacts of subsidies (Source: OFT, 2006, p. 6; Note: The perforated arrows refer to an indirect effect, the non-perforated ones refer to the direct effects).

According to the OFT model shown in Figure 1, it is assumed that the subsidy and plan (characteristic) reasons may have the following effects on market and competition efficiency (OFT, 2004 a \& b), namely:

(1) Boosting low prices by increasing the choice of products for the consumers; subsidies have the potential to enable companies to produce at higher costs or to sell their products at prices above the cost of their production.

(2) Influencing their decisions concerning the production - how much to produce, how to produce and what to charge for it. Such a change will probably have an immediate effect on the competitive process.

(3) Forcing efficient firms out of the market, reducing their long-term investment or cutting down on employment, for example, in order to assure their survival in short term.

(4) Reducing future investments in companies so they act efficiently: If the firms anticipate this low performance and can be compensated for by subsidies, they will have little incentive to be efficient. The incentive acquired at the heart of the competitive process will be suppressed.

(5) Prolonging in time the existence of an unfit company in the market can directly distort the company's incentives to innovate. For example, a subsidy to $R \& D$ that only benefits one company may reduce the incentives of their competitors to invest in research and development (R\&D). 
(6) Encourage companies to use time and resources in an attempt to obtain subsidies. Such resources, especially as they are routinely allocated, are likely to be applied less efficiently.

In addition to the behavioural variables described above, there are other structural variables that play an important role in determining the effectiveness of subsidies: if the beneficiary holds a market power position and if the market is focused in a small number of firms, the incentive will strengthen its position in the market. For instance, Faustino (2013) carried out a study on the impacts of State support on regional and local media in Portugal and concluded that in terms of journalistic product quality, a visible impact on product improvement was observed in most cases (more modern design and graphics, diversified journalistic content, broadening of access platforms) and in terms of pluralism and diversity of voices, an appreciable diversity of regional and local newspapers and local radios has been promoted.

Faustino (2013) also points out that, although supports were important to diminish economic and financial difficulties, it is very difficult to model a support system that enhances the sustainability of journalistic companies in the medium and long term, although they may stimulate the adoption of more competitive management practices by encouraging innovation and market orientation. On the other hand, it is important to know how to adapt the model of state support to the identified market dynamics; for example the free newspapers distribution advent created, as well as the online publications, alternatives and "an effect of replacement in the market, with the free newspapers conquering the readers of paid newspapers and the online publications reinforcing their position as a complementary or a replacement information product (Faustino, 2015).

In fact, through the conjugation and triangulation of the three methodologies (documentary research, analysis of content of interviews and analysis of the OFT model), we intend to obtain a complementarity of perspectives of analysis of the impacts (in the sustainability of the companies and in the promotion of informative pluralism), combining theoretical models with empirical research.

\section{Literature Review and the System of Incentive in Macao and Attributed Amounts}

\section{Support Systems, European Experiences and Information Pluralism}

Citizens need to be informed, while rulers need to be questioned and voices of the opposition need to be heard. However, the free market does not necessarily produce enough conditions for this media panorama to prevail. If, on the one hand, free competition between media companies can generate more efficient production processes at more affordable prices for the consumer, on the other hand, during this process some media companies may be forced to close their doors, resulting in less pluralism, fewer prospects and less social debate.

Press support policies vary according to the political color of the government concerned, the economic situation and the challenges facing the press. For example, resorting to European cases (where different press support models exist), such as the scandinavian and german-speaking countries, it can be said that there are strong local and regional press markets and high readership rates. Austria, Norway, Sweden and Finland have the most developed systems of press subsidies and many of them are originally intended to hold a wide variety of newspapers with different political orientation. In Latin countries, in turn, the number of readers is considerably lower than in the northern European countries, and particular topics, such as sports newspapers, have strengthened their position. Great Britain and Ireland present high rates for the national press. Eastern Europe, however, has a high degree of foreign ownership and a low reading rate. 
The state and the press are traditionally interconnected and since the information media exist, those in power have always tried to influence or control their operations and contents. The objectives and methods used to carry out these actions have been simultaneously creative and diversified. However, while traditional communication theories (e.g., Siebert, Peterson, \& Schramm, 1956) have characterized governments as potentially totalitarian in their ambitions to control the mass media as instruments to support dominant ideologies (as in the case of George Orwell's 1984), these aspects of government policy objectives are rarely used (Neveu, 2004). However, this doesn't stop governments of being accused of using political means to protect national industries or to pursue cultural imperialism.

This battle between economic and cultural interests has marked the political debate for a very long time. Additionally, technological advances, such as the growing importance of the Internet for media distribution, together with the growing importance of international institutions such as the European Union, have reduced the power of governments and national policies to control and guide media systems (Neveu, 2004). Looking only at press policy, blurring the boundaries between print, digital and audiovisual has made it more difficult the specific regulation of written press isolated from audiovisual and telecommunications policy. The proposed solution is therefore to give less importance to the survival of media companies and to value more the way citizens access and interact with each other through the media in order to participate in the social debate (Cuilenburg \& McQuail, 2003).

Over time, the focus of policy implementation has shifted from media companies and publishers to the activities of media users, and these are seen as a discussion forum rather than a mere content provider (McQuail, 1983). This implies a major shift of view of pluralism as being created by communication companies and legislators and then provided to the public to become seen as something created by citizens and by their own means of consumption and active production (Øts, 2009).

The concept of pluralism reflects the diversity of political and cultural voices that have the opportunity to express themselves at a social level. In this process, the media (and mass media, in particular) are seen as important facilitators. For its part, the creation of a policy for the media takes into account the way in which the State, in the scope of its performance, can help promote a landscape of social communication that promotes pluralism in society. The problem is that there are several parallel ideas about the actions that can sustain such pluralism - for instance, the multiplicity of media ownership, the variety of contents and the number of options of existing channels must all be amplified.

The answer will depend on the goal to be achieved (1) if the priority is to avoid the control of the media content through a small number of powerful owners, considering that it is of the utmost importance for each medium to be balanced and fair in its performance, or (2) if the public is privileged to have access to a variety of options. Thus, depending on the interpretation, there are different policy instruments that may appear to be of more rational use - for example, property restrictions or subsidies (Lange \& Van Loon, 1991).

Mcquail (2003, p. 201) also points out that "in the theory of media structure much attention has been paid to issues of uniformity and diversity". Mcquail adds that, beyond this uniformity and diversity, we also have the economic aspect of "monopoly versus competition" (2003, p. 202). The reality is obviously complex and what is seen as being pluralism depends on the combination of a large number of factors; and if the discussion about pluralism focuses only on the aspects that are more directly related with the operations of communication companies, it is possible to identify a set of factors, for instance, the concentration and transparency of ownership, as well as the diversity of journalistic genres, they may be aspects "determinant of pluralism", as 
Figure 2 suggests (Doyle, 2002, p. 14).

The size and richness of the market in terms of audience numbers, market segments and their respective purchasing power for media products provides the basic economic conditions for the number of firms the market can sustain (see Figure 2). It is from this natural perspective that a large market has better conditions to house a large number of newspapers and magazines than a smaller market. If one wants to use the political tools to increase the wealth dimension of this market, there are many options: One is to subsidize the media companies in order to make them less dependent on advertising or consumer financing; and another option passes through indirect subsidies through the decrease of VAT that increases the relative purchasing power of consumers (Neveu, 2004).
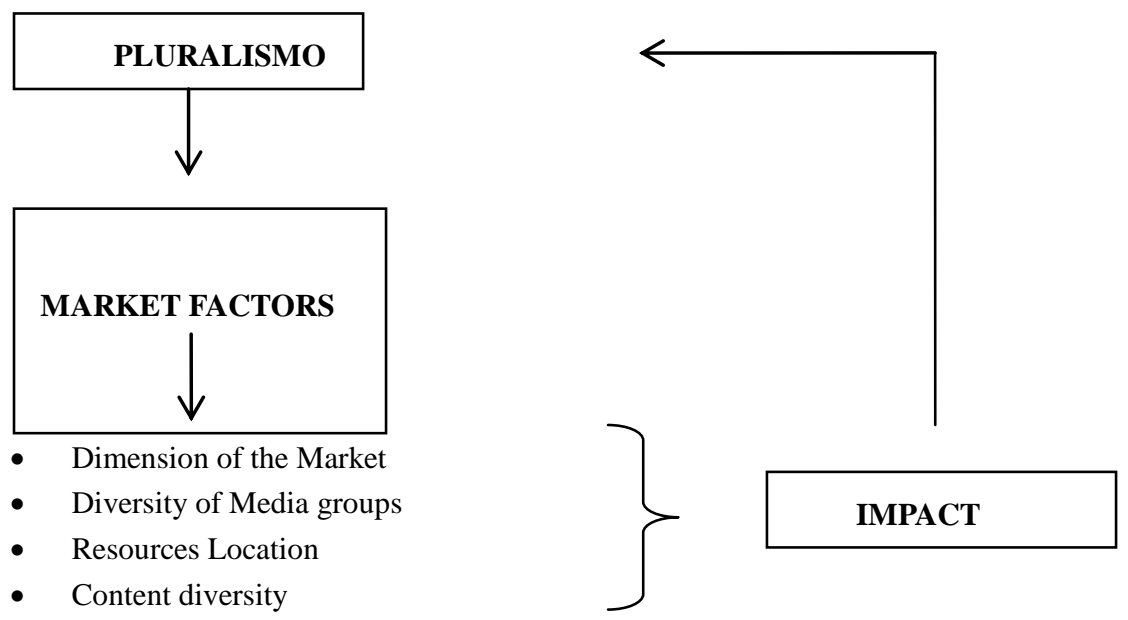

Figure 2. Market factors and their impact on pluralism-OPTION 1.

Table 2

Market Factors and Their Impact on Pluralism-OPTION 2

\begin{tabular}{|c|c|c|c|c|}
\hline Risk domains & Risk areas & Provenance & Distribution & Use \\
\hline \multirow{3}{*}{ Normative objectives } & Cultural Pluralism & \begin{tabular}{|l|}
$L I$ \\
$S d I$ \\
$E I$
\end{tabular} & \begin{tabular}{|l}
$L I$ \\
$S d I$ \\
$E I$
\end{tabular} & \begin{tabular}{|l}
$L I$ \\
$S d I$ \\
$E I$
\end{tabular} \\
\hline & Political Pluralism & \begin{tabular}{|l|}
$L I$ \\
$S d I$ \\
$E I$ \\
\end{tabular} & \begin{tabular}{|l|}
$L I$ \\
$S d I$ \\
$E I$ \\
\end{tabular} & \begin{tabular}{|l}
$L I$ \\
$S d I$ \\
$E I$
\end{tabular} \\
\hline & Geographical Pluralism & \begin{tabular}{|l|}
$L I$ \\
$S d I$ \\
$E I$
\end{tabular} & \begin{tabular}{|l}
$L I$ \\
$S d I$ \\
$E I$
\end{tabular} & \begin{tabular}{|l}
$L I$ \\
$S d I$ \\
$E I$
\end{tabular} \\
\hline \multirow{2}{*}{ Operational Means } & Pluralism of Property and Control & \begin{tabular}{|l|}
$L I$ \\
$S d I$ \\
$E I$
\end{tabular} & \begin{tabular}{|l|}
$L I$ \\
$S d I$ \\
$E I$
\end{tabular} & \begin{tabular}{|l}
$L I$ \\
$S d I$ \\
$E I$
\end{tabular} \\
\hline & $\begin{array}{l}\text { Diversity of Media and Gender } \\
\text { [male and female] }\end{array}$ & \begin{tabular}{|l|}
$L I$ \\
$S d I$ \\
$E I$
\end{tabular} & \begin{tabular}{|l|}
$L I$ \\
$S d I$ \\
$E I$
\end{tabular} & \begin{tabular}{|l}
$L I$ \\
$S d I$ \\
$E I$
\end{tabular} \\
\hline
\end{tabular}

Notes. Fonte: "Independent Study on Indicators for Media Pluralism in the Member States-Towards a Risk-Based Approach”-Final Report, Leuven, July 2009, page 13. LI-Legal Indicators. SdI-Sociodemographic Indicators. EI-Economic Indicators.

On the other hand, the diversity of owners and channels constitutes information that allows answering how the control and power over the media landscape is distributed. Market ownership and concentration have 
always been a controversial topic in the development of media policies and their effects on pluralism operate at the most diverse levels. In fact, some voices claim that free markets with owners of responsible media companies will always be a burden for democracy and pluralism (Baker, 2007). In order to understand this controversy it is necessary to recognize that market concentration is a double-edged sword. From the economic point of view, the market concentration has the potential to reduce the duplication of activities in industry and thus to stimulate production efficiency by encouraging more efficient use of media production.

According to Faustino (2016) the major media groups have come to be consolidated in order to optimize their resources and develop capacity to innovate with competitive advantages, namely through the adoption of different strategies and management practices, including:

(1) Maximizing human and material resources to gain competitiveness;

(2) Approaching media businesses from an integrated and multimedia perspective;

(3) Creating a portfolio of products and media services and diversifying revenues;

(4) Exploiting synergies in the production and distribution of multiplatform contents;

(5) Internationalizing contents and trademarks in other Portuguese-speaking countries;

(6) Strengthening the cooperation with technology and telecommunications companies.

This means that while on the one hand a less concentrated media sector can maintain a large number of independent media, a more concentrated sector empowers a better economic position of each producer to create superior and more diverse content. Thus, some authors argue that concentration of ownership and pluralism may be incompatible (Cavallin, 1995), while others argue, for example, that cross-ownership of the media can increase production quality and diversity of content (Napoli, 2006; Van Der Wurff, 2005). This dichotomy has also been a dilemma for those that make press policy where there is no answer as to if pluralism is more easily achieved by maintaining a large number of different newspapers on the market or if it is better to allow for a greater concentration of ownership and thereby enable the surviving newspapers to exist and compete for audiences and publicity with others types of media. ${ }^{1}$

It should also be noted that how resources are consolidated and distributed among market players will determine how different media companies have access to and use production resources. Is the market dominated by a small group of strong agents? Are there bottlenecks in distribution that exclude other key players in the market? Do the media companies have co-collaboration structures? It is therefore imperative for policy makers to restrict dominant positions, by carefully monitoring vertical bottlenecks - for example, how a single owner of a distribution infrastructure includes or excludes firms that use the same infrastructure. The State has also attempted to encourage better collaboration between newspaper holding companies, particularly through distribution, technology or advertising sales. Conditional grants and competition law are the basic tools of this process.

In short, there are a number of forms of press incentives that can be worked on by policy-makers. Although aware that it may be restricting the discussion that follows the question of subsidies, we will present below a versatile toolbox:

\footnotetext{
1 The legislator has a number of tools to regulate this type of issues, in particular competition laws which define the extent to which media companies are allowed to acquire their competitors. The European Union has tried for a period of time to set a 30 percent ownership limit for each Member State, but due to the general variation in market conditions these uniform measures have proved to be of little practical use. Alternatively, direct subsidies to the weaker players on the market can provide them with the financial means to temporarily resist competitors' proposals and maintain their independence.
} 
(1) A number of countries opt for indirect subsidies, such as reducing VAT on newspapers in order to increase their potential market, or sponsoring their distribution to adolescents (Belgium, France and Spain). Other options include the reduction of postal charges already applied in countries such as Austria or the Netherlands.

(2) Another solution lies in direct financial subsidies, which are allocated to increase newspaper survival rates in times of market concentration, when the public and advertising revenues alone are not enough. However, there is always a choice as to whether they should be attributed to minority media, start-ups, or other areas where they can be used to encourage pluralism. Some countries, such as France, allocate subsidies more broadly, based on circulation numbers.

(3) Conditional subsidies are also given to newspapers in order to respond to particular behaviors or market structures. A common objective lies in stimulating a more efficient collaboration around the attributed resources. Examples of this include business attribution and renewal systems, education and skills development among workers, technological development and entrepreneurial initiatives.

(4) Other mechanisms already existing in some countries (e.g., England, Sweden, Poland) consist of 'content subsidies' to newspapers (and other private means of communication) that produce the right type and quality of contents.

\section{Model and Amounts of Support Given to the Portuguese Press}

Considering the production costs, the small advertising market and the small number of readers, the MSAR Government revoked Order nr. 122/GM/91, of July 25, - regarding the press support regime of the Territory, - through Executive Order nr. 145/2002, which regulates the system of support by the Government of the Macao Special Administrative Region for periodical publications to ensure adequate conditions for the exercise of the right to information. The entry into force of this order allowed the periodical publications, provided that all the formalities imposed by the articles have been met, receive a direct financial contribution - more commonly designated by subsidy - "destined to cover production costs", as well as direct incentives "to support the financing of projects in the area of modernization, innovation, training and professional qualification and others of relevant interest in the field of social communication".

In 2007, through the Office of Social Communication, \$9,322,000.00 (nine million, three hundred and twelve thousand patacas) were distributed for seventeen periodicals, three of which—Jornal Tribuna de Macau, Hoje Macau and Ponto Final -in Portuguese, each receiving 617,800,00 patacas, and O Clarim which, being weekly, received 352,300,00 patacas. According to Gilberto Lopes, "the significant subsidies that we receive may lead us to question the constraints that arise. There is a very specific weight that stems from this; and the survival of Portuguese-language newspapers depends on institutional announcements and subsidies, so newsrooms have to remain short and dependent". ${ }^{2}$

In MSAR, according to Ricardo Pinto, a former journalist, former director and current owner of the newspaper Ponto Final, "the Portuguese press in Macao did something very positive in 1999, when newspaper owners spoke, united, made a pact in the sense of representing a common voice with the politics, obtaining na equitable advertisement, equal for all no matter what they published. A unique voice that was presented to the government and that to this day still has significant relevance. This common position of the Portuguese press in repudiating ad inicium any possibility of interference is felt to this day, and there are no pressures from the

\footnotetext{
${ }^{2}$ Interview with Gilberto Lopes, director of Rádio Macau, 13 june 2016.
} 
political power or situation in which we saw the future of our projects in danger because of what is written. In Macao I have never experienced situations of a clear attempt of political interference". ${ }^{3}$

Since Macao's political power is so closely linked to economic power, the relationship between newspapers and political power is equally, even indirectly, linked to economic power. In terms of publicity the press in Portuguese language depends in an absolutely overwhelming way of institutional publicity. "At this level relations are established more with political power than with economic power. Firstly we defined that none of us would benefit from any constraints depending on what they published. We conveyed this common position to the Government, which welcomed it and has respected it". 4

According to the information collected from the Macao Social Communication Office, Official Bulletins are published periodically on the website (http://www.io.gov.mo), where the lists of values referring to the financial support granted to individuals and private institutions can be consulted in accordance with Order No. 54/GM/ 97 of 26 August. On the 25th of June 2002, Executive Order No. 145/2002 regulates the supports system by the Government of the Macao Special Administrative Region for periodical publications, in order to ensure adequate conditions for the exercise of the right to information through complementary measures to the dynamization of the sector promoted by the respective economic agents.

Once all the formalities imposed by the articles have been complied with, they will receive a direct financial contribution-more commonly referred to as subsidy - "intended to cover production costs", in addition to direct incentives "destined to support the financing of projects in the field of modernization, innovation, training and professional qualification and others of relevant interest in the field of social communication" (Encarnação, 2008). In this analysis, information was collected on the values obtained from newspapers published in Portuguese, such as the daily newspaper Tribuna de Macau, Ponto Final, Hoje Macau and the weekly newspaper $O$ Clarim (see Table 3 ).

Table 3

Financial Support Granted to Portuguese Publications $(€)$

\begin{tabular}{|c|c|c|c|c|c|c|c|c|c|c|c|}
\hline Publication & 2007 & 2008 & 2009 & 2010 & 2011 & 2012 & 2013 & 2014 & 2015 & 2016 & $\begin{array}{l}\text { Var } \\
2016 / 2007\end{array}$ \\
\hline Jornal Tribuna de Macau & 74,136 & 81,550 & 81,550 & 81,550 & 86,443 & 86,443 & 86,443 & 86,443 & 86,443 & 86,443 & $16.6 \%$ \\
\hline $\begin{array}{l}\text { Ponto Final (Parlagrande } \\
\text { Publishings) }\end{array}$ & 74,136 & 81,550 & 81,550 & 81,550 & 86,443 & 86,443 & 86,443 & 86,443 & 86,443 & 84,801 & $14.4 \%$ \\
\hline O Clarim & 42,276 & 46,504 & 46,504 & 46,504 & 49,294 & 49,294 & 49,294 & 49,294 & 47,660 & 49,294 & $16.6 \%$ \\
\hline $\begin{array}{l}\text { Hoje Macau (Fábrica de } \\
\text { Notícias) }\end{array}$ & 74,136 & 81,550 & 81,550 & 81,550 & & 86,443 & 86,443 & 86,443 & 86,443 & 86,443 & $16.6 \%$ \\
\hline Total & 264,684 & 291,152 & 291,152 & 291,152 & 222,179 & 308,622 & 308,622 & 308,622 & 306,987 & 306,980 & $16.0 \%$ \\
\hline
\end{tabular}

Note. Source: Own elaboration based on information from the Macao Social Communication Office.

- In total subsidy amounts, it can be seen that the newspapers in the period from 2007 to 2014 show a constant increase in the total value of the subsidies granted, presenting in 2005 the value of $€ 190,548$ and increasing to $€ 308,622$ in 2014. With regard to the last two years shown in the table, 2015 and 2016, there is a decrease in the value of the total subsidies related to periodical publications published in Portuguese, assuming respectively the values $€ 306,987$ and $€ 306,980$.

\footnotetext{
${ }^{3}$ Interview with Ricardo Pinto, journalist, administrator and owner of the newspaper Ponto Final, 13 June 2016.

${ }^{4}$ Interview with Ricardo Pinto, journalist, administrator and owner of the newspaper Ponto Final, 13 June 2016.
} 
- In the period from 2014 to 2016, it is possible to verify that the daily newspapers Tribuna de Macao and Hoje Macau maintain the value of the subsidies attributed. The daily newspaper Ponto Final reduces the value of the subsidy granted in 2016 to $€ 84,801$; and to the weekly $O$ Clarim the amount of the subsidy in the year 2015 is reduced to $€ 47,660$, but the following year (2006) it verifies an increase presenting the support of $€ 49,294$.

- It can also be noted that the daily newspapers present higher values of subsidies attributed, varying these subsidies in the range of values from $€ 74,136$ to $€ 86,443$. On the other hand, the weekly newspaper $O$ Clarim presents subsidy values on a much lower scale, with values attributed over the period ranging from $€ 42,276$ to $€ 49,294$.

- Considering the variation of the subsidies granted from the period 2007 to 2016, there was an increase of support granted in $16.6 \%$ for the newspapers Tribuna de Macau, Hoje Macau, and O Clarim. The newspaper Ponto Final presents a smaller variation in the increase of the support granted, with a value of $14.4 \%$.

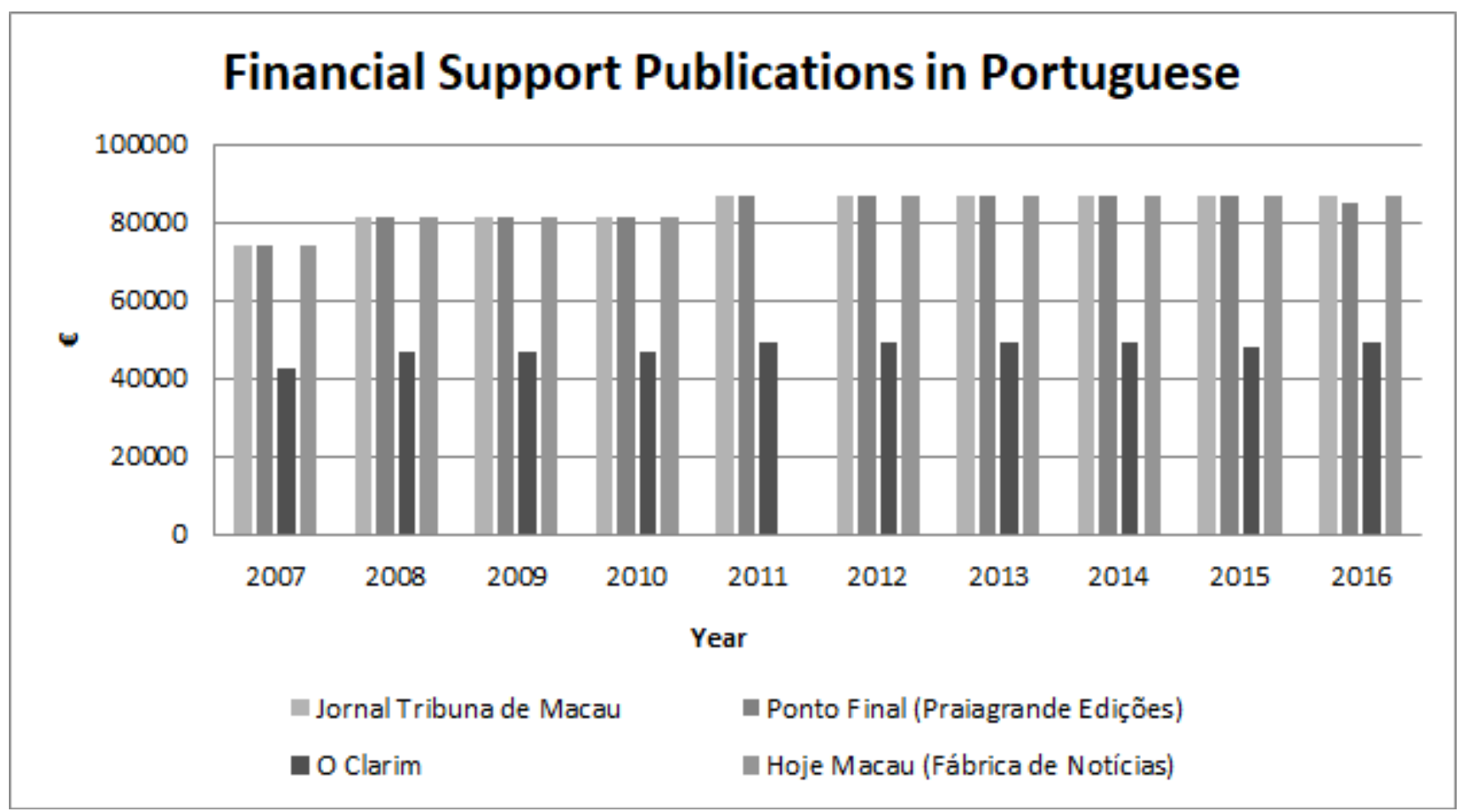

Figure 3. Support to Portuguese publications (Source: Own elaboration based on information from the Macao Social Communication Office).

Table 4

Evolution and Variation of Support to Publications in Portuguese

\begin{tabular}{|c|c|c|c|c|c|c|c|c|c|c|c|c|c|c|c|c|c|c|c|c|c|}
\hline \multirow{2}{*}{$\begin{array}{l}\text { Financial support } \\
\text { (euros) }\end{array}$} & \multicolumn{2}{|c|}{2007} & \multicolumn{2}{|c|}{2008} & \multicolumn{2}{|c|}{2008} & \multicolumn{2}{|c|}{2010} & \multicolumn{2}{|c|}{2011} & \multicolumn{2}{|c|}{2012} & \multicolumn{2}{|c|}{2013} & \multicolumn{2}{|c|}{2014} & \multicolumn{2}{|c|}{2015} & \multicolumn{2}{|c|}{2016} & \multirow{2}{*}{$\begin{array}{c}\text { Var } \\
2016 / 2007\end{array}$} \\
\hline & Value & $\%$ & Value & $\%$ & Value & $\%$ & Value & $\%$ & Value & $\%$ & Value & $\%$ & Value & $\%$ & Value & $\%$ & Value & $\%$ & Value & $\%$ & \\
\hline \begin{tabular}{|l|} 
Total support to \\
publications in Portuguese
\end{tabular} & 264684 & 23,6 & 291152 & 23,7 & 291152 & 23,7 & 291152 & 23,7 & 222179 & 15,9 & 308622 & 23,7 & 308622 & 19,0 & 308622 & 16,2 & 306987 & 15,5 & 306980 & 18,7 & $16,0 \%$ \\
\hline $\begin{array}{l}\text { Total support to } \\
\text { publications }\end{array}$ & 1119360 & 100 & 1229184 & 100 & 1229184 & 100 & 1229184 & 100 & 1394135 & 100 & 1302935 & 100 & 1620391 & 100 & 1910690 & 100 & 1977068 & 100 & 1638434 & 100 & $46,4 \%$ \\
\hline
\end{tabular}

Note. Source: Own elaboration based on information from the Macao Social Communication Office.

In fact, the previous table and figure express the values and variations of supports granted by the Macao Government to the beneficiary entities in the media: 
(1) Publications in Portuguese represent about 23\% of the total in the period 2007-2012, being that in 2011 there was a reduction of the support granted to periodicals (15.9\%), a variation explained by the lack of information about if there was financing to the newspaper Ponto Final.

(2) There is a constant decrease in the total amount of support granted to publications written in Portuguese in the period from 2012 to 2014.

(3) In the most recent year in analysis (2016), was found a significant increase in the value of the support granted to Portuguese publications (18.7\%).

Therefore, on the whole, the support to publications in Portuguese have a variation of $16 \%$ in the period 2007-2016, and the total of supports granted from the Macao Government to the beneficiary entities increased $46,4 \%$.

\section{Analysis of Content in Interviews and Perceptions About Support to Macao Newspapers}

Taking into account that one of the main objectives of this work is to assess the extent to which public support is important for the survival and pluralism of voices in the Macao region, it was considered important to use a methodology based on semi-structured interviews with directors of newspapers in Portuguese published in Macao, as well as the responsible for the Macao Portuguese and English Journalists' Association and director of Televisão de Macau, the editor of Televisão de Macau, the director of Revista Macau, the director of Rádio Macau, an owner and a former owner, as well as the person who writes chronicles in Portuguese newspapers - former ambassador Carlos Frota - and a citizen who for his work appears recurrently on the pages of newspapers-in this case José Luís de Salles Marques, who was mayor of Macao-and a communications consultant and an academic. Of the universe of Portuguese-language (the daily Hoje Macau, Tribuna de Macau and Ponto Final and the weekly Plataforma and O Clarim) only the head of the Hoje Macau, who declined to make statements, was not interviewed. In any case, it is a very robust sample of the universe in question, which allows to draw conclusions significantly representative on the problematic in question. The choice of interviewees - whose interviews took place between 20 May and 20 September 2016-was due to, on one hand, the fact that they possess a high knowledge of the subject matter because of their professional experience and position of responsibility in their newspapers; and, on the other, due to the fact that newspapers are direct beneficiaries of the supports (the readers benefit indirectly) and their impacts manifest themselves first in press companies as an integral part of their business model and financing. In this context, the most relevant aspects of the interviews are presented, whose main questions were to gather the opinion of the directors or editors of some of the Portuguese-speaking media of Macao with regard to government subsidies and plurality and diversity of information with following hypothesis as starting point: H1-The supports are fundamental to the diversity of newspapers in Portuguese in the MSAR; H2-The supports assure the existence of pluralism in newspapers in Portuguese in the MSAR; H3-The supports contribute to the diversity of voices but do not guarantee informative pluralism in the MSAR; and H4-The supports aren't important to promote the pluralism of newspapers in Portuguese in MSAR.

According to José Rocha Dinis, journalist, administrator and owner of the Jornal Tribuna de Macau, "public support has nothing to do with the existence of pluralism or the diversity of voices, because they already existed before financial support. It will have more to do with the professionalism and way of being and 
attitude of who directs the publications". 5 Starting from the hypotheses supports are fundamental for the diversity of the Portuguese-language newspapers, supports guarantee the existence of pluralism in the Portuguese-language newspapers; supports contribute to the diversity of voices but do not guarantee pluralism; supports are not important and there is no pluralism of newpapers in Portuguese, Sérgio Terra, director of the Jornal Tribuna de Macau, explains that his answer does not meet any of the hypotheses suggested, since "there is no direct relationship between the subsidies of the MSAR and the pluralism of Portuguese-language newspapers, seeing as this is a reality, even because there was already a Portuguese press before the implementation of the MSAR. The supports granted by the Macao Government have permitted to ensure of the quality of the newspapers we have today, and it is also important to remember that the Chinese press also benefits from these subsidies". ${ }^{6}$

Contrary to this is José Miguel Encarnação's opinion, editor of the trilingual catholic weekly $O$ Clarim, who considers that "government supports contribute to diversity, as newspapers follow different editorial lines - some more favorable to executive power, some not so much — and to this day the Government has never favored this or that organ to the detriment of the others. Often readers accuse the newspapers of being in the service of the Government or of not publishing certain news so as not to harm their image among the population. Not being able to speak on behalf of the other organs, I only say that $O$ Clarim has never done so, instead seeking to publish the news without value judgments, going to the heart of the issues. I admit, however, that we do not always carry out the exercise of the contradictory for reasons or factors beyond our control". ${ }^{7}$

From these and other positions-see Table 5-it can be concluded that on this same subject there are divergent or even antagonistic opinions. Even if they oscillate between the idea that supports are fundamental to the diversity of Portuguese-language newspapers and that supports contribute to the diversity of voices but do not guarantee pluralism, José Carlos Matias, editor of Televisão de Macau (TDM) in English, ends up choosing the latter. However, "I consider the two to be valid and not mutually exclusive, since supports are fundamental for the diversity of voices, but it cannot be inferred that they are a guarantee of pluralism. In other words: diversity is a sine qua non condition for pluralism, but not sufficient per se. On the other hand, supports do not necessarily guarantee pluralism, since they reside in the editorial options and not in the existence of two, three or four newspapers". 8

Luís Ortet, editor of Revista Macau, is of the opinion that the supports contribute to the diversity of voices but do not guarantee pluralism, since "the public support given by the Macao Government to all the Chinese and Portuguese press in Macao is important to allow plurality and diversity of editorial options, since the only criteria for allocating such subsidies is the periodicity of publications and the fact that newspapers have been published for more than five years. Being that these are the only criteria for awarding subsidies (as well as indirect support, via purchase of advertising spaces) this means that they are awarded regardless of the editorial options. Therefore, newspapers do not feel pressured in any sense and this freedom is effectively exercised in the press in their official languages of Macao. Luís Ortet considers that these supports guarantee diversity, "since this depends on the free will of the owners and directors of the publications. I would say that (given the

\footnotetext{
${ }^{5}$ Interview with José Rocha Dinis, journalist, administrator and owner of the newspaper Jornal Tribuna de Macau, 29 August 2016.

${ }^{6}$ Interview with Sérgio Terra, director of Jornal Tribuna de Macau, 16 August 2016.

7 Interview with José Miguel Encarnação, editor of the weekly $O$ Clarim, 18 August 2016.

8 Interview with José Carlos Matias, editor of the TDM in English and invited professor of the "Media and Society" at the University of São José, Macau, 16 August 2016.
} 
very small dimension of the Macao readers' market) institutional support is a necessary condition (making publications viable, regardless of editorial lines), but it is not a sufficient condition for this diversity to occur effectively since that no longer depends on the Government". 9

Let's also note the words of the director of Rádio Macau, Gilberto Lopes, to understand his position on the same issue: "The public supports granted by the MSAR contribute to the pluralism of Portuguese-language newspapers in Macao as they are a strong support for its existence. The annual subsidy and the advertising paid by the Administration are two of the most important recipes of newspapers. Considering that print runs are scarce and that publicity from companies and institutions not supported by the Administration are not sufficient for the survival of newspapers, government support is thus essential". ${ }^{10}$

Still according to Gilberto Lopes, "this support does not, however, condition the editorial lines of the newspapers. Or rather, contrary to what may seem at first reading, it hasn't been conditioning. Since the creation of the MSAR, the Chief Executive has had as a policy the respect for freedom of press, without pressuring the directors and journalists. Government support may also be interpreted as an obligation to defend and promote the Portuguese language, one of the official languages of the MSAR, as the Basic Law consecrates. The media in Portuguese are probably the most important tool in the defence and promotion of Portuguese. The Reading of Portuguese newspapers enables us to understand that they have different editorial lines, which ensures pluralism. Almost two decades after the transfer of administration we can affirm that there is such pluralism". 11

In the opinion of former ambassador Carlos Frota, the supports essentially contribute to the diversity of voices. He justifies: "Public supports are essential to the survival of the press. Pluralism comes from the way newspapers and journalists see their mission. From my point of view, support is not in itself the factor or guarantor of pluralism or its opposite. It has always seemed well to me the expression of opinions, defenders of an active role of the Portuguese community of Macao, whenever such criticisms are timely and well-founded". ${ }^{12}$

The economist, President of the Institute of European Studies of Macao and former mayor of Macao, Salles Marques, believes that "the official support and rules of publicity of public acts that exist in the MSAR and which also benefit the Portuguese-language media offer support that is almost automatic to them, without the need to negotiate an exchange of favors or any other type whatsoever of interference with freedom of expression. Editorial lines are defined by the owners and editors themselves according to criteria that are exclusively theirs". ${ }^{13}$

Vitor Moutinho, Communication Consultant of the Macau Health Services, former journalist of SIC and $\mathrm{PhD}$ student in Communication Sciences at the University of Minho, Vitor Moutinho, believes that "when supports are defined, in their genesis, they are intended to be compensatory contributions in the chain of effort that the media have to guarantee their function. However, the management of these supports, in particular the moments in which they are released or not, allows readings of sociological, political and economic scope.

\footnotetext{
9 Interview with Luís Ortet, editor of Revista Macau, 15 August 2016.

${ }^{10}$ Interview with Gilberto Lopes, director of Rádio Macau, 3 September 2016.

11 Interview with Gilberto Lopes, director of Rádio Macau, 3 September 2016.

12 Interview with Carlos Frota, former ambassador of Portugal in the Koreas and Indonesia, teacher at University of São José, regular contributor to the Portuguese language press in Macao, 24 September 2016.

${ }^{13}$ Interview with José Luís de Salles Marques, economist, former Mayor of Macau, administrator of the Foundation of the Portuguese School of Macau and President of the Institute of European Studies of Macao, 25 September 2016.
} 
Economist Milton Friedman said that 'there are no free lunches', implying that in the economic arena any payment has or will have an underlying purpose. In the area of communication in Macao, the existence of subsidies, particularly for the Portuguese-speaking media, allows them to compensate, in a fundamental way, the specificity of the market, the absence of publicity and the difficulty of maintaining quality professional staff. Without them, the survival of the media and their diversity would be impossible. Without official support from the MSAR Government nowadays there wouldn't be three newspapers, two weekly newspapers, a radio and a Portuguese-language television channel". ${ }^{14}$

Professor Vítor Teixeira believes that "the Portuguese-language press in Macao (read PLPM) has already reached a plan of possible editorial maturity and independence that, despite needing government support to survive materially and have a public voice, allows it to strive for the best possible pluralism. There is more plural press and less plural press, one would say. There are those who strive to maintain independence and plurality, based on the greater importance of language and community and on the strength of being an element of aggregation and cohesion, and there is the press that exists by publishing with less independence and just looking to survive dry to the raindrops or keep the door open 'smoothly', showing less concern with pluralism, 'right spine' and exemption". 15

Also according to Vítor Teixeira, "we have a good PLPM in Macau, we have a centuries-old press tradition in Macao, it isn't something that was invented in 1999 or just before the handover. There is a Portuguese vox publica, with more or less titles, probably with the ones that have to exist or that the community of Portuguese speakers deserves. But there has been a clear effort in recent years to reconcile survival thanks to the support of the MSAR and pluralism of ideas, positions and assertions. I believe that there is no title that is a 'morning-after pill' of those who give support, or that serves, in Portuguese, 'who orders and pays'. I think that the so called maturity and exemption, volatile or even voluble, not always absolute, because utopian, have been largely achieved in PLPM. The supports are important, decisive, they are somehow an incumbency of the Government; provided they are themselves plural and equal, they are fundamental to the diversity of the Portuguese-language newspapers, but do not (and cannot) clearly or completely inhibit pluralism. That exists, in the measure of the existence of diverse voices, but these cannot be guaranteed by the supports, but by the freedom, exemption and rigor of those who work and give shape to the PLPM. The supports contribute to the extent that they allow titles, several, with their alignments and perspectives, I will not tell trends, but these titles, selling 300 or 400 copies per day (if that much...!) would not survive without decisive government support. However, between the arrival of the 'check' and the work at the newsroom there must be a space of independence or no man's land, separating the two parties very well. Because we need PLPM!"16

The lawyer, television commentator and former owner of Ponto Final, Frederico Rato, launches the question and concludes: "Can the support system of the MSAR Government to periodical publications, whose purpose is, in legal terms, to ensure 'adequate conditions for the exercise of the right to information', have a perverse effect of curtailing freedom of the press because it could affect the independence and autonomy of newspapers and journalists? As far as the information and opinion in Portuguese is concerned, and only on

\footnotetext{
${ }^{14}$ Interview with Vitor Moutinho, Communication Consultant of the Health Services of Macau, former journalist of SIC, $\mathrm{PhD}$ student in Communication Sciences at University of Minho, 15 August 2016.

15 Interview with Vítor Teixeira, Professor at University Católica Portuguesa, PhD in History, PhD in Iconography and Semiotics at University of Roma 1, La Sapienza, 20 September 2016.

16 Interview with Vitor Teixeira, Professor at University Católica Portuguesa, PhD in History, PhD in Iconography and Semiotics at University of Roma 1, La Sapienza, 20 September 2016.
} 
these I can pronounce, I am of opinion that that seems to be the real aspiration of the norm, and the knowledge that I have of the work of the Portuguese information organs since the date of entry into force of this support system (2002), as well as the rules laid down in the diploma of application, which are more objective and less arbitrary than those included in the similar diploma of the Portuguese administration, lead me to the conviction that such a support regime not only doesn't interfere with the free exercise of function and profession, but also represents, as I have already written 'a stimulus to the production and diffusion of information and opinion by the communities in the two official languages, a bet on the continuity of a diversified and plural society, which is enriched in the difference, and a reinforcement of the autonomic capacity of Macao as a distinction factor." $" 17$

Table 5

Trends in the Responses of Portuguese Newspapers in the MSAR

\begin{tabular}{|c|c|c|c|c|c|c|}
\hline \begin{tabular}{|l|} 
Mean of Social \\
Communication \\
\end{tabular} & \begin{tabular}{|l} 
Director or \\
Editor
\end{tabular} & Affirmation & Hypothesis 1 & Hypothesis 2 & Hypothesis 3 & Hypothesis 4 \\
\hline $\begin{array}{l}\text { Daily Tribuna de } \\
\text { Macau }\end{array}$ & Sérgio Terra & $\begin{array}{l}\text { "There is no direct relationship } \\
\text { between the subsidies of the } \\
\text { MSAR and the pluralism of } \\
\text { Portuguese-language } \\
\text { newspapers". }\end{array}$ & & & & $\mathrm{X}$ \\
\hline Weekly $O$ Clarim & $\begin{array}{l}\text { José Miguel } \\
\text { Encarnação }\end{array}$ & $\begin{array}{l}\text { "Government supports } \\
\text { contribute to diversity, as } \\
\text { newspapers follow different } \\
\text { editorial lines and to this date the } \\
\text { Government has never favored } \\
\text { this or that organ to the } \\
\text { detriment of others". }\end{array}$ & $X$ & & & \\
\hline $\begin{array}{l}\text { TDM - Televisão } \\
\text { de Macau }\end{array}$ & $\begin{array}{l}\text { José Carlos } \\
\text { Matias }\end{array}$ & $\begin{array}{l}\text { "Supports are fundamental for } \\
\text { the diversity of voices, but it } \\
\text { cannot be inferred that they are a } \\
\text { guarantee of pluralism". }\end{array}$ & & & $X$ & \\
\hline Rádio Macau & Gilberto Lopes & $\begin{array}{l}\text { "The public supports granted by } \\
\text { the MSAR contribute to the } \\
\text { pluralism of } \\
\text { Portuguese-language newspapers } \\
\text { in Macao as they strongly } \\
\text { support its existence". }\end{array}$ & & $X$ & & \\
\hline Revista Macau & Luís Ortet & $\begin{array}{l}\text { "The public support given by the } \\
\text { Macao Government to all the } \\
\text { Chinese and Portuguese press in } \\
\text { Macao is important in order to } \\
\text { allow the plurality and diversity } \\
\text { of editorial options". }\end{array}$ & $X$ & $X$ & & \\
\hline
\end{tabular}

Note. Source: Own elaboration based on interviews to the directors and editors of newspapers in Macao.

Based on the interview referred to and the analysis carried out on the three dailies and the two weeklies in Portuguese, one can see the existence of plural, sometimes blunt, opinions on local government, with the notorious existence of themes such as Taiwan, which are invariably addressed with care. "In general, the Taiwanese issue is assumed by the Portuguese-language press in the following perspective: Taiwan is not a

17 Interview with Frederico Rato, lawyer, television commentator and former owner of the newspaper Ponto Final, 2 September, 2016. 
country. It has a strange status, it has a form of self-government, a form of advanced Western-style democracy, it has state institutions, it has a president, but it's not a state. Such status creates difficulty in analysis. At TDM, whenever we hire a new journalist in Portugal, the first thing we explain is that Taiwan is not a country. We also explain that it is not necessary to refer to the region as being the renegade province or the rebel province, and that when we give the news about a theme from that area we cannot speak of Head of State. For the sake of correction, and because we are living in the Macao Special Administrative Region of the People's Republic of China, we must be cautious. We must respect the nature of this region, how it relates to the Central Government and the Government of Taiwan, and therefore to reflect this in our content". ${ }^{18}$

Therefore, based on the analysis of the interviews, it can be said that there is a predominance to consider that the allocation of supports (by the MSAR Government) contributes to the existence of positive impact of newspapers in Portuguese, namely verifiable by the agreement of the two first hypotheses: H1-The supports are fundamental to the diversity of newspapers in Portuguese in the MSAR; and H2-The supports guarantee the existence of pluralism in newspapers in Portuguese in the MSAR.

\section{Conclusions and Recommendations}

Macao is a territory characterized by a strong multiculturalism where different communities and their idiosyncrasies coexist. This circumstance optimizes the existence of a very particular media system insofar as, despite the small size of the territory, there are means of communication-newspapers, radio and television stations - that broadcast content in different languages, mainly in Chinese, Portuguese, and English. According to the dimension and population of the territory, Macao has the highest average density in the world-nine daily newspapers in Chinese, three daily in Portuguese, three daily in English, half a dozen weekly in Chinese, one weekly bilingual Portuguese-Chinese and one trilingual in Portuguese, Chinese and English. There are also in the territory two television transmission channels and one radio channel-Rádio Macau,which broadcasts in Chinese and in Portuguese. Both TV channels include one in Chinese and one in Portuguese that also broadcasts the news in English.

Even though the relation of these means with the political power approximates the media system of the territory of which Hallin and Mancini (2004) defined as the pluralistic polarized model, where curiously the authors also situate the South of Europe, the truth is that the professional practices of Portuguese-speaking journalists in the Macao Special Administrative Region differ from those practiced in Portugal, which is due to the fact that they come from the conjugation of the Western journalism model and the local reality. Unlike the situation of the press in the Western world, the Macao press is not in a state of decline or financial fragility, thus being able to play a key role in what concerns the promotion of pluralism and diversity of information, ideas and values.

For a population of 601,000 people $^{19}$ in the MSAR, media operators, namely newspapers, may reflect a considerable diversity, variety, plurality and the opportunity to choose editorial lines. The local press contains titles with neutral, favorable or contrary positions to the Government, with positions assumed before its readers, with very distinct and plural editorial lines. In this context, it can also be concluded that there is awareness that, despite their relative importance, even by the small number of runs-about one thousand per newspaper in each

\footnotetext{
18 Interview with João Francisco Pinto, President of the Macao Portuguese and English Press Association and director of Macau Television (TDM), 20 May, 2016.

${ }^{19} \mathrm{http}: / /$ countrymeters.info/en/Macau.
} 
edition - and even fewer readers, the Portuguese-language press of Macao allows people to access the facts from a common cultural view, leading to the great majority of Portuguese who do not speak Chinese have access to information with a cultural and linguistic code. However, the question of the relevance of the existence of so many Chinese-language newspapers but also in Portuguese is effectively debatable, including from the point of view of its economic and financial sustainability.

Although it is possible to conclude that nowadays there is a dependency on the support granted by the MSAR Government, it should be noted that on the Portuguese side of the press, the survival of newspapers (namely Ponto Final, Tribuna de Macau, Macau Hoje — which made way to Hoje Macau - and O Clarim) through public supports already existed until 1999-year in which Macao became a special autonomous region of China. The only more recent publication is the Plataforma, which will have to survive by itself until it completes 5 years running, the minimum period necessary to gain access to Government supports.

Newspaper operators have remained stable over the years, the policy of press subsidies has been maintained and is based on the fact that the Macao market is reduced in order to be enabled by the revenues generated by the information market (advertising and readers), and it is assumed that the press, in order to exercise its right to inform and convey opinions, needs an indiscriminate support from the Government. Such subsidy policy was extended from the birth of the MSAR, a factor that has allowed the maintenance and continuity of diversity over decades.

On the other hand, it is concluded that, because it is not a competitive information market, Macao newspapers move away from the paradigm of newspapers (in some international markets, including Portugal) that measure the interests they have, calibrating them from bellow, in the sense that they can reach more people, giving emphasis to lighter issues of society. In this context, it can also be concluded that the fact that the Government finances newspapers in Portuguese also means that there is a greater plurality of opinions and news diversity. From the point of view of the presence of public space in the newspapers, it can be said that there are several distinctive ways of looking at the question, namely:

(1) The public space as a whole, including the different communities, especially the Chinese, predominant in number, enters in Portuguese newspapers in a minority way, especially because it is given voice to the same sources and one does not escape the usual paradigm;

(2) One can consider the Portuguese community of Macau privileged, being the only one in the diaspora that has a television channel, a radio channel and five newspapers in Portuguese language;

(3) Due mainly to the issue of language, news about the Chinese community and other communities are scarce, denoting a lack of human capacity of journalists to embrace these interests.

Concerning the obstacles encountered during the investigation, the greatest difficulty was the access to some sources of information and indicators that would allow to better evaluate the performance of journalistic companies (audiences, circulation, sales and revenues) and their degree of dependence on the subsidies. Although it can be concluded that subsidies represent a very significant revenue component, it would have been interesting to conclude this weight more precisely. For this reason, one of the possible recommendations to deepen or complement this study will be to gather economic and financial information from journalistic companies in order to create performance indicators according to the types of revenues generated (subsidies, sales, advertising and other revenues) and relate it to the models of business organization, business models and management practices, among other possible approaches. These analyzes may also provide relevant information to assess the existence or not of a socio-economic context that enhances pluralism of information, 
including the editorial autonomy of newsrooms. It will also be interesting to analyze the extent to which the MSAR model of supports is compatible with the transformation of business and journalistic models in the context of migration to digital.

In summary, the conditions for granting subsidies in Macao establish that the conditions for access to this subsidy are indifferent to the property, the editorial line, the number of pages published, referring only to the language in which it is published - Chinese and Portuguese - and the number of years of publication —at least five. Being subsidized, on a number of fronts, in particular through institutional publicity of the courts and public services, even with small print runs and without the need for commercial advertising, survival, as long as such subsidies remain, will be potentially guaranteed. Relating the model of supports that prevails in the MSAR with the OFT model, it can be concluded that it is a system in which its modeling (design and criteria) does not present significant concerns with the rationality of management practices, although it can be affirmed that the model enhances stability in business management and ensures minimum conditions of survival in the market. It is not, therefore, a support system whose rational is the greatest competitiveness in the sector, and does not contribute to encourage the adoption of innovative practices. And the big question is: How long can the MSAR Government maintain this incentive system?

In this sense, while recognizing the specificities of the MSAR (small market and two official languages), it is envisaged that in the future the model of support will have to be rethoughtand the OFT model (described in point 1.2) may constitute a benchmark (Faustino, 20013), namely the six conceptual steps that should be taken to design and evaluate their impacts: i) Policy Rationale; ii) Subsidy Design; iii) Effect on the Recipient Behaviour; iv) Market Outcomes; v) Subsidy effects on the competitor's; and vi) Subsidy effects on allocative, productive and dynamic efficiency.

\section{References}

Arons de Carvalho, A., \& Faustino, P. (2010). Estudo de Impacto dos Incentivos Directos Concedidos pelo Estado aos Órgãos de Comunicação Social Regional e Local (Study of impact of direct incentives granted by the State to the regional and local social communication organs). Retrieved from https://www.gmcs.pt

Baker, C. E. (2007). Media concentration and democracy: Why ownership matters. Cambridge: Cambridge University Press.

Cuilenburg, J. V., \& McQuail, D. (2003). Media policy paradigm shifts: Towards a new communications policy paradigm. European Journal of Communication, 18(2), 181-207.

Doyle, G. (2002). Media ownership: The economics and politics of convergence and concentration in the UK and European Media. London: Sage Publications.

Faustino, P. (2013). Media governance, state subsidies and impacts on regional press and radio. Journalism and Mass Communication, 3(4), 768-785.

Faustino, P. (2015). Media concentration in Portugal. In E. Eli NOAM (Ed.), Media concentration and ownership around the world: Who owns the world's media? New York: Oxford University Press.

Faustino, P. (2016). Market structure and innovation policies in Portugal. In H. Van Kranenburg (Ed.), Innovation policies in the European News Media Industry. German: Springer.

Gustafsson, K. (1995). Media structure and the state: Concepts, issues, measures. Suécia: Goteborg University.

Hallin, D. C., \& Mancini, P. (2004). Comparing media systems: Three models of media and politics. Cambridge, UK: Cambridge University Press.

Lange, A., \& Van Loon, A. (1991). Pluralism, concentration and competition in the media sector. IDATE/IVIR.

McQuail, D. (1983). Mass communication theory. London: Sage Publications.

Mcquail, D. (2003). Media accountability and freedom of publication. New York: Oxford University Press.

Murschetz, P., \& Faustino, P. (2010). Government subsidies to Newspapers in Europe-Are they still effective? Proceedings from IX World Media Economics and Management Conference. Savana University, Bogotá, Colômbia. 
Napoli, P. M. (2006). Issues in media management and the public interest. In B. A. Albarran, M. S. Chan-Olmsted, \& O. M. Wirth (Eds.), Handbook of Media Management and Economics. Mahwah, NJ: Lawrence Erlbaum Associates.

Neveu, É. (2004). Sociologia do Jornalismo. São Paulo: Edições Loyola.

Office of Fair Trading (OFT). (2004). Market definition-Understanding competition law. Retrieved from https://www.gov.uk/government/uploads/system/uploads/attachment_data/file/284423/oft403.pdf

Office of Fair Trading (OFT). (2007). Office of Fair Trading. Retrieved from https://www.gov.uk/government/uploads/system/uploads/attachment_data/file/231349/0339.pdf

Øts, M. (2009). Efficient servants of pluralism or marginalized media policy tools?: The case of Swedish Press subsidies. Journal of CommunicationInquiry, 33(4), 376-392.

Øts, M. (2013). Incentivos Europeus à Imprensa (European Incentives to the Press). In P. Faustino (Ed.), Gestão, Economia e Políticas para os Media Regionais e Locais (Management, Economy and Politics to the Regional and Local Media). Lisboa: Media XXI (in process of conclusion).

Siebert, F. S., Peterson, T., \& Schramm, W. (1956). Four theories of the press: The authoritarian, libertarian, social responsibility, and Soviet Communist concepts of what the press should be and do. Chicago: University of Illinois Press.

Van der Wurff, R. (2005). Competition, concentration and diversity in European Television markets. Journal of Cultural Economics, 29(4), 249-75. 